\title{
Dublin Ireland: a city addressing challenging water supply, management, and governance issues
}

\author{
$\underline{\text { Mary Kelly-Quinn }}^{1}, \underline{\text { Sean Blacklocke }}^{2}$, Michael Bruen $^{2}$, Rav Earle $^{3}$, Eoin O'Neill $^{4}, \underline{\text { John O'Sullivan }}^{2}$ and Patrick Purcell $^{2}$
}

\begin{abstract}
The population of Dublin City and its suburbs currently stands at 1.3 million and is projected to reach 2.1 million by 2022. There is pressure on its water supply system (inadequate catchment sources, ageing infrastructure including treatment facilities, and distribution network) with little or no spare capacity despite Ireland's relatively high rainfall that is well distributed throughout the year; albeit the greatest rainfall occurs in the west and southwest and at some remove from Dublin. The current governance approach to addressing the projected water supply deficit relies heavily on a combination of identifying new supply sources to secure the long-term water supply needs of the city together with an intense drive toward achieving "demand-side" reduced usage and conservation targets in accordance with EU benchmarks for various individual and sectoral users. This potentially emerging crisis of water scarcity in Dublin, with drivers including population growth, greater industrial and institutional demands, migration, and climate change, has generated one of the most significant public water works projects proposed in Irish history, which is to abstract raw water from the Shannon River Basin in the midland region and, following treatment, pump it to a storage reservoir in a cut-away bog before piping to the Greater Dublin Area. The preparations for this scheme have brought to the forefront some longstanding Irish water resources governance issues and challenges. This provides a unique opportunity and imperative at this time to take a more comprehensive look at the decision-making process in this regard, one done in the context of new European and national policies requiring incorporation of integrated planning to sustain ecosystem services, water resources management, water services management, and flood defense principles, and one taking account of the current unprecedented state of flux in which water resources management institutions in Ireland, and in particular Dublin, find themselves following years of unconsolidated legislation and stand-alone institutions.
\end{abstract}

Key Words: demand management; Dublin; full cost recovery; governance; water supply

\section{INTRODUCTION}

The population of the greater Dublin area (GDA) is projected to grow significantly over the coming decades from its current 1.3 million. Somewhere in the region of 550 million liters per day of water are currently required (for domestic water supply alone usage is in the range 140 to 150 liters per person per day) and it is estimated that if demand behavior/culture remains relatively unchanged and factors such as population growth, migration/urbanization, climate change, and innovation/ technological balance regarding supply/demand are considered, this figure will increase to 800 million liters per day by 2031 (Dublin City Council 2010a). There is pressure on the current water supply infrastructure to meet ever-increasing demand with little or no spare capacity, despite the fact that Ireland has relatively high rainfall that is well distributed throughout the year. Water shortages are not uncommon in the city in summers when the preceding winter has had lower than average rainfall.

This comes at a time in which Ireland is being required to comprehensively revise its water pricing policies pursuant to the European Water Framework Directive (WFD). "Full cost recovery" under the WFD requires Member States to develop pricing schemes that take account of and recover not only the financial costs of providing water and sewerage services, e.g., capital, engineering, operation and maintenance, administrative, but also environmental and resource costs. In simplest terms, environmental costs are equivalent to the hypothetical expenditures to remediate damages to water resources, e.g., fish habitat, brought about by possibly illegal, poorly regulated, or even perfectly legal abstractions or effluents/runoff to streams, i.e., "externalized costs." These environmental costs are to be accounted for and "internalized" on the externalizing establishments or sectors, i.e., households, industry, and agriculture, via charges. Resource costs are opportunity costs. Therefore, in the case of the Dublin water supply proposal under the WFD, if some volume of water from the Shannon River Basin is transferred to the Eastern River Basin, and in doing so it can be shown that this volume of water is no longer put to its longterm highest valued use, there is a resource cost associated with that transfer that should be accounted for, priced, and recovered. Conversely, if diverting a volume of water makes the use of that water more efficient, such as would be the case if a seasonal interbasin transfer could alleviate flood risks in the Shannon River Basin while also buffering a chronic potable water supply deficit in Dublin, such a transaction would have a negative resource cost and should be added back to the interbasin transfer's balance sheet as a benefit offsetting other costs. In reality, the proposal for the Shannon transfer obviously has multiple costs and benefits and thus "full cost accounting" of all of the financial, environmental, and resource costs is both required and necessary before an appropriate charging regime for the use of this water can be developed.

In light of this, we attempt in this paper to highlight some of the key challenges for water resources management and governance currently confronting Dublin City and Ireland as a nation, and discuss how these challenges might best be addressed within the framework of Ireland's new emerging water governance institutions. Although many of the issues raised are not individually novel, the combination of challenges faced by Dublin within the newly emerging national governance framework presents a unique opportunity to provide baseline information

${ }^{1}$ School of Biology \& Environmental Science, University College Dublin, ${ }^{2}$ School of Civil, Structural \& Environmental Engineering, University College Dublin, ${ }^{3}$ International Water Association, ${ }^{4}$ School of Geography, Planning \& Environmental Policy, University College Dublin 
for future analysis on the evolution of water governance approaches in Ireland. Although the impetus for the paper is the issue of future supply of potable water to the GDA's water users, tangential and broader aspects of water resources management are considered in the context of Ireland's ongoing efforts to incorporate fundamental principles of the Integrated Water Resources Management (IWRM) concept into its myriad of water governance institutions.

It is noteworthy that although the term governance is variably interpreted (Franks 2004), it is used here as the "range of political, social, economic and administrative systems that are in place" (as defined by Rogers and Hall 2003:7) to manage water resources. There is not one single, ideal governance model, suitable for all situations, and there is general agreement that good governance can be achieved with a variety of different paradigms, including elements of top-down, bottom-up, market forces and collaborative networks.

Many advocate that water governance should only deal with the processes and institutions that make decisions about water resources (e.g., Lautze et al. 2011) although the principles of effective water governance, compiled by the Global Water Partnership (Rogers and Hall 2003) and set out in UN Water documents (UNESCO 2009) also include outcomes as highlighted by Lautze et al. (2011). The 12 principles are: open, transparent, participative, accountable, effective, coherent, efficient, communicative, equitable, integrative, sustainable, and ethical. As noted by Lautze et al. (2011) the criteria efficient, equitable, integrative, effective, and sustainable are all components of IWRM. Lautze et al. (2011) propose a redefinition of water governance to exclude outcome criteria. However, in practice, the authors feel it is very difficult to separate the decisionmaking process and institutions from the outcomes. Although it is recognized that in some quarters there is still considerable debate on whether government intervention, regardless of how "good" the governance, can ever lead to relatively efficient and effective water resource use, the reality is that most if not all modern societies with pressing water issues, particularly in urban areas, inherently rely on some combination of market forces and government institutions to effectuate the use of water resources.

\section{CHALLENGES FOR WATER SUPPLY AND GOVERNANCE}

As mentioned, Dublin, in common with other growing cities of similar scale, faces major challenges in relation to how it manages its water resources. Cities struggling to keep pace with population and demographic changes are not unique, however, collectively the combination of factors in relation to Dublin create an inordinately challenging situation for those attempting to plan for the city's current and future water resources needs. Some of these key challenges, inter alia, include:

- Geographic mismatches between water availability and water users

- A legacy of problems resulting from the historic evolution of Dublin's water services system

- The city's ongoing dependence on a Victorian era infrastructure

- Emerging development and population growth
- An historic focus on water management through supply expansion

- An absence of domestic water charges

- Emerging climate change uncertainties

In Ireland there is a mismatch between the highest availability of water for abstraction and the highest concentration of potable water users.

The east of the country has on average 150 rainfall days per year yielding between 750 and $1000 \mathrm{~mm}$ of rainfall (Met Éireann 2014). The 225 days of rainfall in the west generally average between 1000 and $1250 \mathrm{~mm}$ per year but exceed $2000 \mathrm{~mm}$ per year in many mountainous areas. Dublin City sits in the east of the country at the foot of the Dublin-Wicklow Mountains. Although there are several medium to small rivers and two canals within the GDA there are no substantial natural lakes within $50 \mathrm{~km}$ of the city. Furthermore, no major aquifers exist within Dublin City Council's jurisdictional boundary.

The historic development of Dublin's water supply underlies some of its current problems.

Sourcing of water within its own jurisdiction and from the jurisdictions of the other local authorities is a practice that is likely to continue to create problems for the GDA in the future. The city has a system of water supply that has been in existence for approximately three-quarters of a millennium. The medieval city of Dublin's water supply was drawn from watercourses within the city environs (Rivers Poddle and Dodder and the Grand Canal) until the middle of the 19th century, when the supply became deficient both in quality and quantity for the growing population. The Dublin Corporation, as the Dublin City Council was formerly known, Waterworks Act of 1861 enabled a new source of water from a neighboring county at Roundwood, County Wicklow to be developed. The water from this source was conveyed to a large open service reservoir at Stillorgan (Fig. 1). A further Parliamentary Act of 1880 enabled the development of impoundment reservoirs at Bohernabreena on the River Dodder, from which raw water was conveyed to a slow sand filtration plant at Ballyboden (Fig. 1). This plant was subsequently replaced in 1955 with a physico-chemical treatment system. These storage schemes provided sufficient water to Dublin City until the 1930s when a rapid population expansion occurred, from 505,654 in 1926 to 718,333 in 1961, while the population of the country as a whole remained relatively static during this period,. The consumption of water, which had remained static for over 60 years, began to grow. When it transpired that the Electricity Supply Board (ESB) planned to develop a hydro-electric scheme by constructing a dam on the River Liffey at Poulaphuca, County Wicklow, Dublin Corporation decided to become a partner, and this arrangement was legalized in the Liffey Reservoir Act of 1936. This scheme, with a treatment plant at Ballymore Eustace, County Kildare, provided for a virtual doubling of the available supply at that time to the city south of the River Liffey and sufficed until about 1970 . To cater for increased water demand in north Dublin, provision was made during the construction of another dam on the River Liffey at Leixlip, County Kildare by the ESB for the development of a water supply, and construction of the first phase of a treatment works and pumping station commenced in 1966. 
Following treatment at the Leixlip works, water is pumped to a service reservoir at Ballycoolan, from where it flows gravitationally to the distribution area of north County Dublin (Fig. 1). A timeline summarizing key dates in the development of Dublin's water supply system is presented in Figure 2. Since the 1970s, the water treatment plant at Ballymore Eustace has been in a state of nearly constant expansion and is now at its treatment capacity design limit. As development extended beyond the administrative area of the city over the decades, Dublin City Council assumed the role of lead local authority, i.e., network operator, for water and wastewater services provision across what has become known as the Dublin Region Water Supply Area $\left(\mathrm{WSA}^{[1]}\right)$, a supply area that includes all of Dublin and also parts of the adjacent counties of Wickow, Kildare, and Meath. Dublin City Council was the coordinating authority for the Eastern River Basin District in the first cycle of Water Framework Directive activities, the coordinating authority for the Eastern Region Waste Management, and a designated key player with respect to the floods, Marine Strategy Framework, industrial emissions, and other Directives. Also, Dublin City Council is pivotal in the integration envisioned in the new National Spatial Strategy where planning, utility infrastructure, ecosystem services, flood defence, and many other water resource related challenges must be addressed in a holistic manner and with multicriteria decision making that optimizes solutions for all rather than maximizes solutions for specific sectors or interested stakeholders. In the current second cycle of WFD activities, a larger, national coordinating role has been given to the Environmental Protection Agency.

Fig. 1. Schematic layout of Dublin City's water supply system.

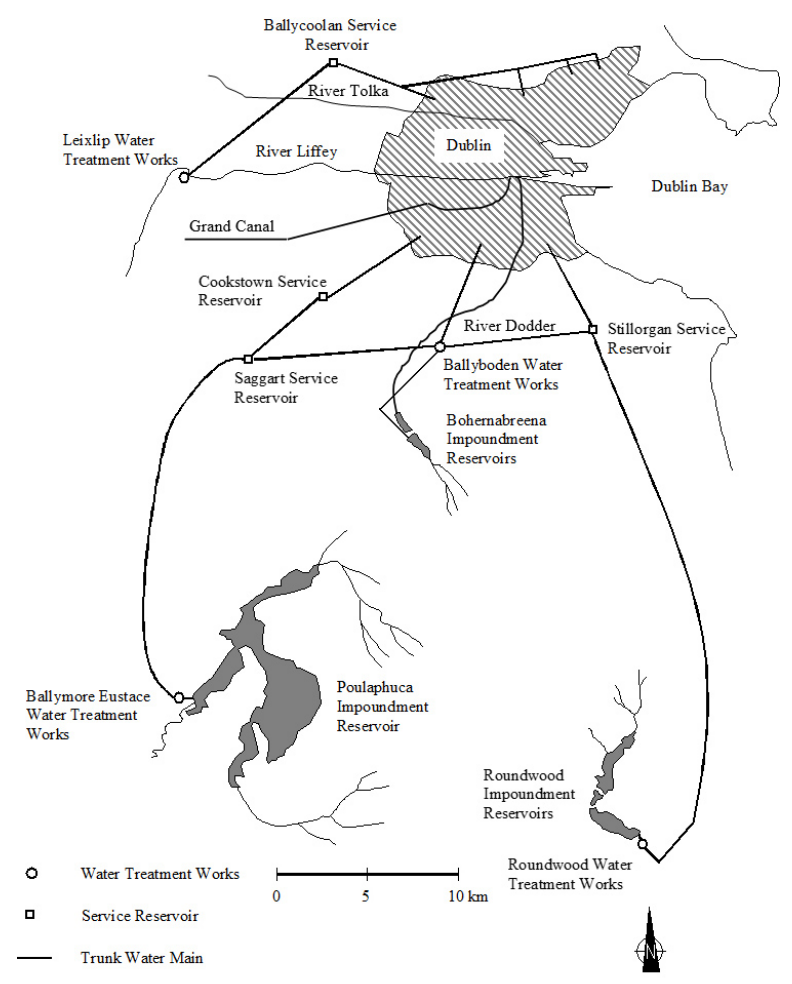

Fig. 2. Timeline showing key dates in the development of Dublin City's water supply system.

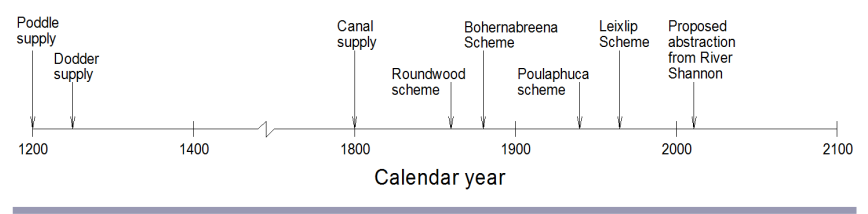

Dublin's ongoing dependence on a Victorian era infrastructure is costly.

Environmental legislation in the late 19th century and early 20th century brought about gradual improvements in urban sanitation and housing conditions in Irish cities, particularly Dublin (Bannon 1985). However, much of the city is reliant on a distribution network that now dates back to Victorian times (1800s), particularly in the city centre comprising mainly old cast iron and ductile iron mains. Current losses due to leakage are estimated to be in the region of 29\% (Dublin City Council 2010b), and even with the use of the most modern technologies to locate and remediate faulty lines, only relatively minor volumes of water have been retained to date.

Demand is increasing as the population of the GDA continues to grow.

Ireland has seen very strong population growth rates of $\sim 30 \%$ over the two decades between 1991 and 2011 reaching 4.6 million today. Of this, 1.3 million reside in Dublin (Central Statistics Office 2012) representing a significant increase from the 1.2 million living in the city and its suburbs in 2006. However, as outlined by Redmond et al. (2012), regional variations are apparent. Looking at population change back to 1991 within the GDA, Dublin City recorded population growth of $24 \%$ over this period whereas there was exceptional growth of $63 \%$ experienced in the surrounding Mid-East Region, which comprises the Counties of Wicklow, Kildare, and Meath, over the same period. Redmond et al. (2012) also noted that these Dublin figures mask exceptional internal population shifts with some areas recording growth as high as $79 \%$ compared to $10 \%$ elsewhere.

Future population projections, contained in the Regional Planning Guidelines, for the Greater Dublin Area comprising Dublin and Mid-East Region, envisage a national population of $\sim 5.4$ million by 2022 with 2.1 million or $40 \%$ of those residing in the GDA by 2022 (Table 1). On the basis of these high population scenarios being achieved, the Irish Academy of Engineering (2007) identified the possibility of a national population of 8 million by 2100 , with a GDA population share maintained at $40 \%$.

The continuation of population dispersal across the GDA, consistent with an urban sprawl settlement pattern, presents challenges for those charged with the responsibility of providing infrastructure in an efficient and cost-effective way (Redmond et al. 2012). Demographic trends also indicate net growth in the number of households associated with a continuing decline in average household size. This generates supply challenges because there are economies of scale in water consumption associated with larger households relative to smaller households. 
Table 1. Regional population targets and scenarios.

\begin{tabular}{lcccccc}
\hline \hline & 2008 & 2010 & 2016 & 2022 & 2011 Actual & $\begin{array}{c}\text { Difference between 2011 } \\
\text { Actual and 2010 Target (\%) }\end{array}$ \\
\hline Dublin & $1,217,800$ & $1,256,900$ & $1,361,200$ & $1,464,200$ & $1,270,603$ & 1.09 \\
Mid East & 514,500 & 540,000 & 594,600 & 639,700 & 530,437 & -1.77 \\
State & $4,422,000$ & $4,584,900$ & $4,997,000$ & $5,375,200$ & $4,581,269$ & -0.079 \\
\hline
\end{tabular}

Source: Adapted from Redmond et al. (2012).

To improve the functioning of the GDA and the efficiency of service delivery, Regional Planning Guidelines for the GDA have provided for the majority of future population growth to be targeted within the metropolitan area, i.e., the contiguous builtup area, with the balance of growth being primarily targeted at other key growth locations along transport corridors within the wider hinterland of the GDA, as illustrated in Fig. 3. In addition, GDA Regional Planning Guidelines have been published in relation to flooding risk assessment and guidelines are also being prepared in relation to integration with the requirements of the Water Framework Directive and the Marine Strategy Framework Directive.

Fig. 3. Greater Dublin Area: metropolitan and hinterland areas.

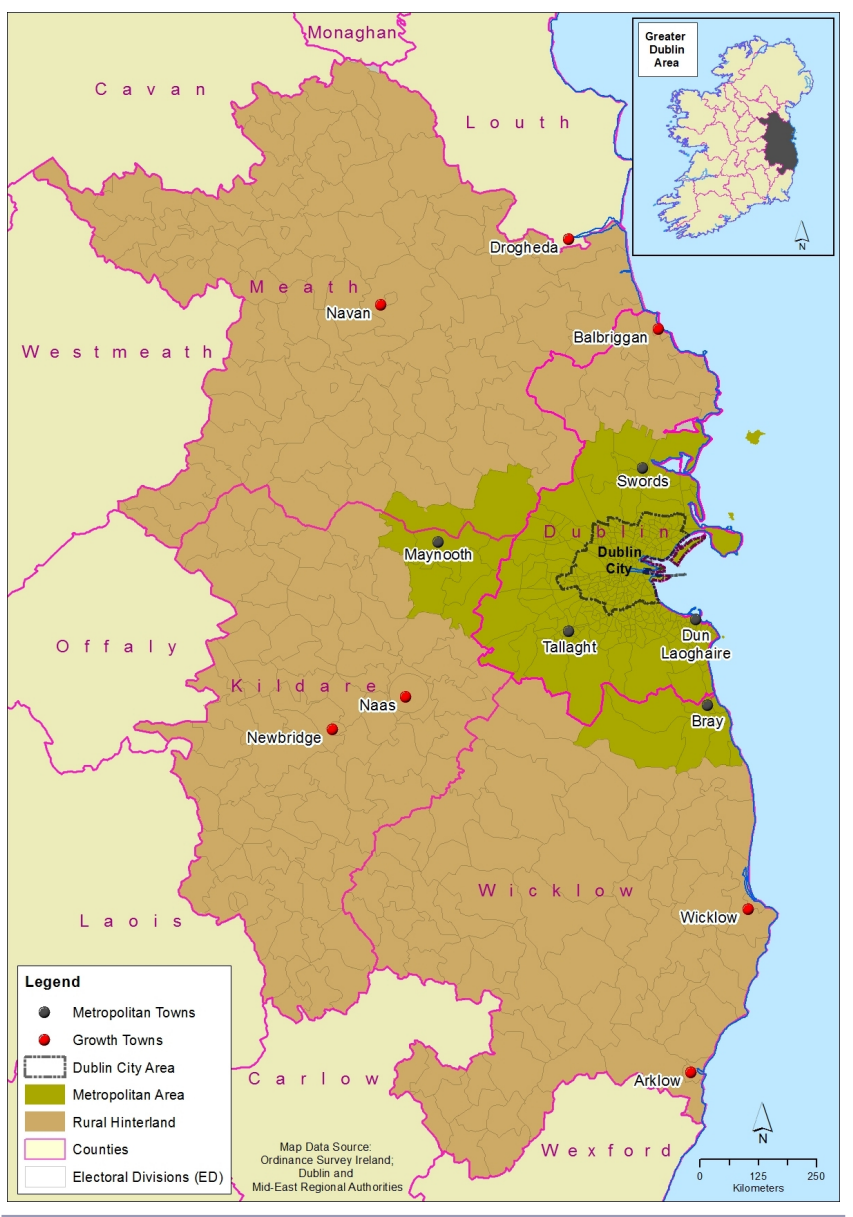

Given the sustained growth in the size of the economy until the demise of the "Celtic Tiger" period in 2008 and thereafter, and the associated growth in population and employment, the regional imbalance between population and access to water resources has reached a tipping point with demand for treated water in the Dublin Region WSA, that includes parts of the MidEast counties, currently exceeding the sustainable production capacity of the existing major water treatment plants (Dublin City Council 2010b). Notwithstanding the current economic downturn of the last five years that has resulted in what are considered to be short-term reduced water demand growth rates, Dublin City Council (2010b) has recognized that if not addressed, water shortages are likely to become more common and that for the horizon to 2040, supply levels will need to increase from the current value of 550 million liters/day to 800 million liters/day. This projected deficit is based on the most likely planning and climate change scenario.

\section{Water management in Ireland has historically focused on expanding water supply.}

Demand growth only in recent years has been met by some improved leakage management, water conservation initiatives, and by operating the water treatment plants that service the city beyond their sustainable production capacity. As a consequence, there is little redundancy or "headroom" in the system and this was evidenced during the prolonged cold spell in the winters of 2009 and 2010 that identified a major vulnerability to Dublin's water supply in freezing conditions. The issues were twofold. First, the length and severity of the cold spell allowed the frost line to reach the depth of buried pipes (typically $750 \mathrm{~mm}$ below the surface), causing numerous bursts in the distribution network. The situation was compounded by the high prevalence of poor condition, older pipe stock within the system, a state known to contribute to high levels of unaccounted-for-water (Trow and Farley 2006). Heavy leakage coincided with the return of warmer ambient temperatures. It is likely that this vulnerability can be addressed in the future by aligning Irish construction standards in such matters more closely with those present in colder countries or where climate change projections are similar to that of Ireland. Second, and undoubtedly contributed to by the fact that Ireland, at that time, did not charge for domestic water usage, short-term demand increases resulted from homeowners letting water taps run continuously during this cold period to prevent water freezing in domestic pipes. This produced a situation where, although ample supply remained in raw water reservoirs, stores of treated water diminished rapidly and required water authorities to curtail or temporarily cut supplies in some areas. Similar curtailments to the Dublin water supply have also arisen in periods of drought where insufficient raw water is available to meet demand. 
Here again, as in the past, water shortages are most likely to be addressed by exploiting new sources of supply and the need for these was highlighted in 1996 in a high-level assessment of Dublin's water supplies (DEHLG 1996). Therefore, with all existing water supply sources fully developed to their sustainable supply limits (627 mega-liters) a strategic regional project known as the "Water Supply Project Dublin Region" has been developed to plan the delivery of a long-term water supply for the GDA. This has involved the evaluation of various potential water supply options and combinations of options that included abstraction/ storage options from Lough Derg in the Shannon River Basin and from the River Barrow, groundwater abstraction from the nearby Kildare Aquifer (no major aquifers exist within the Dublin City boundary), and desalination of Irish Sea water to meet the future needs of the Dublin Region WSA. Although the Kildare aquifer is the largest sand and gravel aquifer in the country with an annual average recharge of $284 \mathrm{~mm}$ (Misstear et al. 2008) and could support an additional supply of 5 mega-liters/day (Kildare County Council 1999), the aquifer supports the base flow in a number of other river headwaters and some sensitive ecosystems, e.g., Pollardstown Fen, a natural heritage site of national importance. Furthermore, results of monitoring this aquifer during and after the construction of a section of interurban motorway, the Kildare bypass, in a cutting that intersected the top of the aquifer indicates a large and relatively long-lived response to water extraction (M. Bruen, G. van Wirdum, T. Hayes, E. Farrell, L. Brown, P. Johnston, P. Devine, and J. Coppinger, 2010, unpublished manuscript) and any development of it as a water supply resource would therefore need to be balanced against adverse impacts on its ecological function. Although desalination was also assessed as an alternative for supplementing Dublin's water supply, the energy requirement and the associated cost of treatment were considered significantly higher than the other alternatives. For example it was estimated that the energy requirement for an east coast desalination plant would be three to four times that required for the Shannon water transfer scheme (Dublin City Council 2010b) even with tremendous advances in leading edge technologies such as "forward osmosis."

Thus, the Shannon abstraction option emerged from a feasibility study of these options in 2005 and detailed assessments of the hydrological and environmental impacts of this scheme are currently being considered. The adopted plan proposes the abstraction of raw water from Lough Derg (River Shannon, $\sim 120$ $\mathrm{km}$ from Dublin) and pumping the abstracted water through a new pipeline to a proposed storage reservoir at a cut-away bog in the Irish midlands (in County Offaly) with treated water transported via pipeline to the Dublin Region (Dublin City Council 2010b). Although technical feasibility issues have been carefully analyzed, as outlined above, less attention seems to have been devoted to local concerns relating to: the level of public consultation generally; and, to consultation specifically about a potential loss of regional resources to sustain Dublin growth while, inter alia, a high leakage rate persists there.

In conjunction with increasing the supply, a limited range of water demand management measures to augment, rather than provide an alternative water supply source, are being implemented in Dublin. Measures currently in place include leakage reduction through repair and rehabilitation of the existing water main infrastructure, controls of mains water pressures and reduction of consumption and leakage in the nondomestic sector by volumetric metering and water charging since 2008. Some programs of measures have also been implemented previously to improve the management of existing supplies of potable water. Between 1996 and 2002, the Dublin Region Water Conservation Project that implemented a real-time telemetric system for monitoring the distribution of water in the city facilitated the implementation of efficient leakage management plans that reduced leakage in the water supply network from $43 \%$ to $29 \%$ (Dublin City Council 2010b). The Dublin Region Watermains Rehabilitation Project (2007 - 2012) represents a further program of investment in the city's infrastructure that replaces older segments of the network, together with further planned investment targets a $20 \%$ leakage rate by 2040 . A rate of this order, although high in comparison to other European cities (Forfás 2008), is considered to be the "economic level" for a Victorian network of the type in Dublin (Dublin City Council 2010b). Local authorities in the Dublin Region WSA have also engaged in water demand management educational initiatives such as the "Mr. Drippy" school campaign and "Tap Tips" (http://www.taptips.ie), both of which provide guidance on reducing water consumption in homes and gardens. Although significant efforts to date to capitalize upon demand-side management opportunities have been undertaken by Dublin City Council, the development of these options is still relatively novel in Ireland when compared to the more conventional supply expansion options. As such, opportunities for further developing these and additional measures likely remain underexploited, e.g., widespread use of conservation devices such as low-flow toilet and showerhead adaptations, "purple line" installations for the reuse of storm water for nonsanitary water uses, rainwater collection systems for showering, etc.

Charges for domestic water supplies are not yet in place.

Costs for the provision of domestic water utilities in Ireland, including Dublin City, are currently met in large part by the Exchequer. National and European policies however, have recognized for some time now that full cost recovery for water services was to be in place by 2010 in line with the "Cost Recovery Principles" (Article 9) of the Water Framework Directive (EC 2000, Forfás 2008), and although this has remained a central plank of funding strategies for national water resources management, the introduction of universal domestic water charges in Ireland will apply from late 2014, following the set-up of Irish Water, the new single water utility company for the entire country. The downturn in the economic cycle and the associated decline in exchequer revenue, together with the requirement under the terms of the EU/-IMF bailout forced a government rethink on the matter. At peak there was an annual investment of almost $€ 600 \mathrm{~m}$ in Irish water services infrastructure via the Water Services Investment Programme (WSIP) but this was almost halved during the economic downturn. Consequently, the government has announced that charging for domestic water usage will commence in the final quarter of 2014 with the first bills being issued by Irish Water to household consumers in January 2015. At this time, the installation of water meters in up to $90 \%$ of residential properties (it is estimated that $10 \%$ of Irish properties are unsuitable for metering, e.g., many apartments) has commenced, with a roll-out period of four years, after which volumetric charging of domestic water will be fully operational, although the timescale remains 
subject to some debate. It has been decided that a free allowance (30,000 liters) will be provided to all users with charges being incurred only when this free threshold is exceeded. Additional allowances will be allocated to children. This will be subject to review in 2016.

The legislation setting up Irish Water does not make explicit provision for full cost recovery, nor does it set out a basis for charges other than to stipulate that following adoption by the government, they will be regulated by the Commissioner for Energy Regulation, who also has responsibility for regulating Irish Water. It is expected that initial water charges will be based on estimates of the cost of supplying water and wastewater services, however it may be some years before the full cost is known. A private members amendment bill was initiated in 2014 to provide for the accounts of Irish Water to be subject to inspection by the Comptroller and Auditor General, but has not been enacted. Thus, full details of costs may not be made public through this forum. The Act does provide for borrowing (up to $€ 500,000,000)$ by Irish Water and the guaranteeing of such borrowing by the government. Any monies paid by the government on foot of this guarantee have to be repaid by Irish Water and indirect indication in the legislation that it is intended to be self-financing. Interestingly however, the legislation does provide for any shortfall in repayments to be made up from government funds, allowing the possibility of losses and thus less than full cost recovery.

Nevertheless, volumetric charging is expected to reverse the upward trend in per capita consumption that is currently of the order of 150 1/person/day to 130 1/person/day by 2030 (Dublin City Council 2010b). It should be noted however, that although introducing domestic water charges is expected to reduce consumption, at least initially, this reduction itself is not likely to be sufficient to meet Dublin City's longer term supply objectives. It is also less clear whether the expected initial reduction in consumption because of charges will be maintained in the longer term.

Uncertainty in the context of climate change has yet to be fully addressed.

It is widely recognized that climate change will pose further challenges for the management and governance of water resources. In the case of Ireland, climate change is predicted to cause an increase in average summer/autumn temperatures toward the end of this century of 3.0 to $3.4^{\circ} \mathrm{C}$ and average precipitation amounts beyond 2060 are for autumns and winters to be wetter by $15 \%$ to $20 \%$ and for summers to be dryer by $10 \%$ to $18 \%$ (McElwain and Sweeney 2003, Dunne et al. 2008). Also expected are increases in the frequency of extreme flooding events (Leahy and Kiely 2011). Although regional differences are not very clear from the simulations, the largest increases in summer/ autumn temperatures and the largest decreases in summer precipitation are expected in the southeast and eastern parts of Ireland, which includes Dublin. The increase in average autumn/ winter precipitation amounts are expected to be greater than the decrease in summer amounts so the net annual prediction is for more precipitation. However, from a water supply point of view, the expected increase in temporal variability means that benefits of this can only be achieved if the increase in autumn/winter rainfall can be stored and used in the dryer summer periods.
Dublin does have access to a number of large reservoirs for water supply, but they are currently, as previously mentioned, operating close to full capacity. In the latter half of this century, the possibilities of increasing the usable storage in these lakes will arise, but this is likely to be costly and controversial.

\section{THE CURRENT ADMINISTRATIVE AND NEW EVOLVING GOVERNANCE STRUCTURES}

Apart from the climate change, urbanization, hydrological, hydraulic, metering, and other supply challenges outlined above, Ireland, and thus Dublin City is also currently undergoing an unprecedented transformation in its link to government departments and agencies, institutional entities, governance structures, and reporting mechanisms under the government's Policy Document entitled Putting People First with far-reaching implications for all local and public authority staff in relation to legal, financial, personnel, relocation, and administrative/ reporting arrangements with respect to water services delivery. Each local authority's new public water services section will interact with Irish Water under a Service Level Agreement (SLA), but in fact the broader range of water resource interests and statutory requirements will also have to be managed as a "seamless" extension of the SLA water services arrangements to include all local and public authorities cited in the transposition of the Water Framework Directive and their designated staff working under non-SLA arrangements to complete the "hydrological cycle," so to speak. Before describing what is currently known about the newly forming governance structures for Ireland's, and consequently the GDA's, water services and water resources management, a brief review of the most recent and transitioning current structure is warranted.

\section{Most recent and current structure}

This section outlines, in summary, the roles and responsibilities of the key actors and organizations involved in the provision, control, finance, and regulation of water services in Ireland in most recent history and/or at present. However, it should be noted that this precise institutional arrangement is in an unprecedented state of flux.

The European Union (EU) formulates relevant water quality legislation at European level, which is transposed into national law by the Irish parliament. The EU also has a monitoring function and can pursue legal cases against member countries of the EU for failure to implement EU directives. The Irish Department of the Environment, Community and Local Government (DECLG) is a central government department responsible for setting policy and controlling capital expenditure on water services provision. The Environmental Protection Agency (EPA) is the technical and environmental regulator for drinking water and wastewater services in Ireland.

Formerly the local authorities (City and County Councils) had the primary responsibility for the provision of the urban public water and wastewater services, in addition to large rural water supply schemes. Rural Group Water Schemes are voluntary cooperatives providing potable water on a small scale to customers in some rural communities. They are developed, operated, and maintained by the user group. Individual supplies for single dwellings or industrial enterprises are quite common in rural Ireland. The local authorities are responsible for the 
supervision of any group water schemes and private water supplies in their areas and for carrying out various water-related inspection and enforcement activities. The EPA has statutory responsibility for the supervision of the quality of water and wastewater services delivered by the local authorities.

In addition to being a basic public health requirement, water services are also recognized as a potential critical constraint on population growth and the supply of land for enterprise development. Therefore, water supply and wastewater services are also key considerations in the urban planning process at regional (e.g., Regional Planning Guidelines for the GDA) and city or county plan scales (see Gkartzios and Scott 2009 for more details about the Irish planning system). Before the creation of Irish Water, the Irish Local Authorities were required to consider their own individual water services investment strategy when making development plans that provide for future development patterns. In this context, Dublin had already identified the provision of a sustainable water supply as a potential development constraint, where, as previously outlined, there is substantial and continuing population growth. However, as noted earlier, there were major administrative and resource availability challenges.

The Irish Government recently announced the transfer of responsibility for water services provision from the local authorities to a single public water utility, Irish Water, (Irish Government 2013). Currently, in Ireland, direct charges for the provision of water and wastewater services to domestic customers will, as previously mentioned, commence with the introduction of domestic water metering. Nondomestic customers currently pay water charges on the basis of metered consumption according to prices set by their local authority. This is usually a combination of a flat standing charge and a metered charge based on actual volumes used. There is an established methodology for the assessment of what represents full cost recovery of nondomestic water and sewerage charges. Furthermore, local authorities also levy a (once-off) development contribution in respect of public infrastructure, including water and wastewater infrastructure ${ }^{[2]}$, benefiting development in an area as a condition of planning permission (for discussion see Clinch and O'Neill 2010). However, the lack of a published methodology on full cost accounting and recovery pursuant to the definition of water services under the Water Framework Directive is a significant omission to date on the part of the Irish Government, which, if not addressed, may have repercussions for the future of water resources governance in Ireland.

In 2011, Ireland conceded to the European Commission that it had made an improper interpretation of the definition of "water services" in materials submitted to the Commission pursuant to the requirements of the "Cost Recovery principles of Article 9 of the Water Framework Directive," i.e., with respect to full cost accounting of water services and charging for water services. Ireland now concedes that the externalized costs associated with all uses of water, "including the environmental and resource costs of water use,"i.e., not just those inherent in the provision of water and sewerage services, must be identified, and a charging system incorporating the objective of internalizing these costs as well must be implemented nationwide (EC 2012:1). However, although essential for the transparency and integrity of a cost structure, determining the methods by which full cost recovery will be made operational in the context of future infrastructural investment and charging structures with regard to the true value of water, is complex. This complexity is reflected in the different interpretations of the water pricing principle in the WFD across EU member states and to the activities and sectors to which the cost recovery applies. In the run-up to the 2014 local and European elections, the issue of applying water charges in Ireland for domestic customers was at the forefront of the national political agenda. Although the full details of the pricing structure have yet to be finalized, it is accepted, as previously mentioned, that bills, either in full or in part, will be linked to the amount of water consumed or discarded. This, to a degree, will be consistent with the requirements of the WFD in that the policy will incentivize the efficient use of water and thereby contribute to its environmental objectives.

\section{Newly forming governance structure}

Reform of public water services in Ireland has led to the formation of Irish Water, a public water utility, within the Bord Gas Éireann (BGE-Irish Gas Supply Company) group, that is set to take over supply of potable water and management of wastewater services from local authorities. The key driver for establishment of Irish Water is essentially a requirement of the Irish economy bail-out arrangements in 2009 with the "Troika" (International Monetary Fund, World Bank, and the European Union). Irish Water is specifically charged with furthering the objective to internalize the costs of providing potable water and sewerage services for all users, including domestic consumers, in accordance with the "Cost Recovery principles" of Article 9 of the Water Framework Directive. The Troika requires that Ireland charge domestic customers directly for drinking water in line with the legislation, policy, and procedures of the EU as is being implemented in all other EU Member States, and in the context of nonrevenue water/ unaccounted-for water being as high as $40 \%$ in some urban areas, including Dublin. Funding this drinking water supply service indirectly through taxation was deemed to be inefficient, with no clear incentive to tackle the leakages and conserve water, and also with potential productivity and efficiency gains achievable through a single public water utility for the whole country benefiting from economics of scale (DECLG 2012). The Troika further required the introduction of appropriate emerging technology, including better organization/management, reliable metering and smart networks, and customer-focused service delivery with a transparent and trustworthy billing system. The Irish Government concluded that the investment required to update the old Irish infrastructure could not be met by available near-term public funds alone. Accordingly, a major deciding factor in establishing Irish Water was its inherent ability to directly access private capital to bring the system of drinking water sourcing/abstraction, treatment/production, storage, and distribution up to the required standards. Meeting the requirements of the Drinking Water Directive and the Urban Waste Water Treatment (UWWT) Directive, even in a relatively cost-effective manner, requires significant investment, far beyond what the government can currently provide.

The key policy document driving the organizational issues associated with Irish Water is entitled Putting People First. Its contents communicate the current government's aim to radically reform local government in Ireland by, among other things, the integration and harmonization of utility and ecosystem services at a regional level. 
Incorporating the principles of IWRM into decision making and management

Integrated Water Resources Management (IWRM) has been defined as "the co-ordinated development and management of water, land and related resources in order to maximize the resultant economic and social welfare in an equitable manner without compromising the sustainability of vital ecosystems" (GWP 2000:22). Fittingly for this paper, the Dublin International Convention on Water and Environment Issues (held in January 1992 to approve a statement on Water for the United Nations Rio Conference) provided one of the important steps toward global recognition of the need for IWRM. The important aspects are: (i) It recognizes all the uses of water; and (ii) It recognizes that water resources developments must be considered in conjunction with other natural resources. Although there are many who question whether IWRM can actually work in practice (e.g., Biswas 2008), most would likely agree with the objectives of IWRM and support some of its fundamentals, e.g., multidisciplinary approach or consultation with stakeholders. There is no recognition that there are practical limits to the range and number of factors that can be addressed by IWRM in any particular setting. This is in contrast to the Water Framework Directive, which sets the limits on measures "not involving excessive costs." Also, it is not clear that the complex institutional frameworks and linkages necessary for IWRM do not inhibit the flexibility and adaptability of the organizations involved (e.g., Fischhendler and Heikkila 2010). In Dublin's case, the critical nature of its water supply-demand balance will require this flexibility, particularly to implement new and novel solutions given the need to acquire new sources and storages outside its administrative boundaries.

\section{Progress to date and limitations with respect to governance}

There is already a rationalization of the number of local authorities and Putting People First establishes three regions for Ireland (Connaught/Ulster, Eastern/Midlands, and Southern Region). Legislation for Irish Water has been enacted, but much of the detail is left to its implementation by statutory instruments or ministerial orders that will define in more detail what powers, duties, responsibilities, and accountabilities will be enshrined for Irish Water in relation to several key areas. These are expected to include: (1) capital and operating finance issues; (2) commencement date for collection of water charges; (3) planning/ development issues under the Water Services Investment Programme (WSIP); (4) Competent authorities for making decisions with regard to the requirements for Strategic Environmental Assessment, Environmental Impact Assessment, Nature Impact Statement/Appropriate Assessment, etc. and what thresholds will apply for strategic infrastructure development via An Bord Pleanála; (5) licensing issues regarding the operations/ activities of "works" and "pipe networks"; (6) monitoring; and (7) relationships with competent authorities governing uses of natural waters and the funding streams for ecosystem services, flood/drought management, etc.

To date the Minister has provided for Irish Water to be a fully state-owned subsidiary company of BGE (an existing stateowned company and itself a regulated utility), and will be established as a public water utility operating nationally and subject to various regulatory, planning, financial, and other requirements of institutions of state including, inter alia, Department for Finance, Department of Environment,
Community and Local Government (DECLG), National Parks and Wildlife Service, Health Service Executive, Environmental Protection Agency, planning authorities, and An Bord Pleanála, in addition to requiring statutory consultation in a number of areas. Primary and secondary legislation has only recently been enacted and the success (or otherwise) of their implementation is yet to be seen. However, ultimately Irish Water, through its Board and $\mathrm{CEO}$, is required to be accountable to the various interdepartmental and Oireachtas (parliamentary) committees (as is the parent Company BGE), in addition to complying with all relevant EU and Irish legislation relating to Drinking Water Directives, UWWT Directives, etc. However, it is legitimate to deliberate as to whether Irish Water will be sufficiently accountable to the people of Ireland relative to the previous more localized governance arrangements. At the national level, there is ongoing national bargaining between the government/DECLG and the unions representing the local authority/Sanitary Authority Workers at various grades of employment (engineers, fitters, etc.). With a myriad of employment contracts with widely varying terms and conditions of employment, including pension arrangements, in many instances unions have called for noncooperation. However, 12-year Service Level Agreements (SLAs) have been agreed to address the relationships between Irish Water (and its regional offices) and each sanitary service, fire service, etc. as part of each local authority following full implementation of the government policy Putting People First. Separate detailed public authority agreements are also being drafted with reference to good working relations with relevant public authorities that are competent authorities in certain areas such as Office of Public Works (responsible for drainage), Electricity Supply Board, Health Service Executive, Environmental Protection Agency, etc. Several protocols have now been drafted in relation to a range of operational issues for Irish Water and its regional offices, e.g., procurement, monitoring, training-human capital via Water Services National Training Group, Accreditation/CPD, and these are the subject of discussion between the City and County Managers Association (especially its Water Committee), the Water Services Transition Office, the existing Sanitary Authorities, and many other interested parties.

Putting People First also aspires to greater public engagement and consultation and democratization of decision making in relation to water services. Accordingly Ireland is perhaps juggling with the ultimate all-inclusive, multicriteria, decision-making framework (i.e., multidiscipline, mutisectoral, and multiscale), the common criticism of which is that such an approach inevitably leads to protracted decision making.

\section{DISCUSSION}

Dublin as an EU capital is unique in terms of its archaeology, built and natural heritage, and hydro-geology, all of which pose huge challenges to get the balance right between economic and infrastructural demands and its long-standing commitment to the preservation of ecological services, water aesthetics, etc. On the other hand the GDA is faced with the challenges of population increase/migration and climate change on a scale that exacerbates the national geographic mismatch between rainfall and water demand.

As noted earlier, water supplies for cities throughout the world are now often assessed in the context of IWRM. Furthermore, IWRM is often set in the context of water governance and its 
spatial scale is an important issue, and although there is general agreement that the natural spatial scale for IWRM is the catchment, it is not as clear what is (if any) an appropriate scale for good governance structures (Bai et al. 2010). Consequently water governance initiatives take place at a variety of spatial scales: there are many reports of water governance at national scales, e.g., Israel (Fischhendler and Heikkila 2010), South Africa (Schreiner and van Koppen 2003), Mexico (OECD 2013a), Sweden (Aspegren et al. 1997; P. Balmér, unpublished manuscript); at city scales, e.g., Harare (Manzungu and Mabiza 2004); and at regional scales, e.g., Andalusia and Catalonia (Bel et al. 2013), California (Kallis et al. 2009, Lubell and Lippert 2010), Awash Basin, Ethiopia (Water Governance Centre 2013), and Ruaha River Basin, Tanzania (Lankford et al. 2004). Good water governance also has an international dimension. For instance, it has been adopted as one of three key elements in the Asian Development Bank's strategy for poverty reduction (ADB 2004) together with pro-poor sustainable economic growth and inclusive social development. The European Union has addressed the issue of water quality and managed a degree of collaboration and coordination, but its Water Framework Directive is insufficiently comprehensive to qualify as IWRM (Rahaman et al. 2004). The Organisation for Economic Cooperation and Development (OECD) has made the assertion that "the current water crisis is not a crisis of scarcity but a crisis of mismanagement, with strong public governance features"(OECD 2011:17). This is due to institutional fragmentation, poorly managed multilevel governance, unclear allocation of roles, lack of integrity and transparency, poor economic regulation, and poorly drafted legislation (OECD 2013b). To this list could be added that inadequate measurement of performance (including definitions of appropriate indicators) causes deficiencies in accountability and transparency. In contrast, the latter can be enhanced through social learning, promoted by experimentation that is being increasingly recognized (Bos et al. 2013), especially in the early stages of a transition between governance structures (Rijke et al. 2013). This is particularly relevant to Dublin (and Ireland) because it is in transition from water services being provided by local authorities to a governance system whereby water services are provided by a public water utility operating nationally that is subject to economic regulation. In general, governance structures that discourage private investment in the water sector have not been looked upon favorably by the majority of those promoting the concept of good governance, particularly with respect to developing countries (Helmer and Hespanhol 1997).

At present, the Irish Government's stated intent in relation to governance is that by 2017 , Dublin City Council will cease to be the provider of water and wastewater utilities for the Dublin Region WSA and Irish Water will take over these responsibilities in full. Although some details regarding the intended administrative structure of the organization are available, it remains unclear whether or to what extent this new organization will serve as the "integrator" of Dublin City's and the other competent authorities' broader water resources management activities. It would appear that any future administrative framework for the management of Dublin City's water services, as now interpreted by the Irish Government, would have Irish Water managing potable water and wastewater treatment services with perhaps some other umbrella institution or combinations of institutions overseeing the activities of the likes of the Office of Public Works (managing flood control), the Inland and Sea Fisheries Boards (managing fisheries), local authorities and An Bord Pleanála (managing land use and development), Geological Survey of Ireland (technical services and advice in relation to groundwater), Waterways Ireland (managing inland waters navigation), EPA and local authorities (managing surface water quality), etc. The nature of how these authorities are organized remains unclear but will have a great bearing on the extent to which water governance in Ireland and the GDA are generally in line with the principles of IWRM. Supply options for the GDA have yet to go through the rigors of a complete Strategic Environmental Assessment, Environmental Impact Assessment, Appropriate Assessment and their associated public participation processes. It is as yet unclear how these options will be assessed within the emerging governance structures.

However, implementation of such a radical change will result in numerous political, governance, and public acceptability concerns. Concerns articulated to date relate in large part to:

- The lack of regional balance in development, and the sustained growth of Dublin "at the expense" of growth and development in other regions (see Clinch and O'Neill 2009 for review of regional policy initiatives and concerns.),

- The associated potential for overabstractions of water by Dublin City water users at the expense of those who rely upon the Shannon River Basin water environment for their welfare as well habitats and biodiversity, and

- The lack of local legitimacy in the management of the Shannon River Basin with Dublin City having a disproportionate and inappropriate role in its future management (EEA 2012).

Also, the principle of transferring ownership and control of water services infrastructure, which is currently subject to local democratic accountability via locally elected councillors, to a public water utility without any direct democratic accountability is likely to be central to the debate over the future governance responsibilities developed for Irish Water. Given that Irish Water will benefit from a very substantial transfer of assets from local authorities (historic capital investment worth billions of euro, and development contribution funds collected) and also receive control of a critical environmental and life-sustaining natural resource, accountability to the citizen and the consumer will be paramount. However, it is not yet clear how Irish Water will be held accountable in practice, so the development of an accountable and transparent governance structure will be critical to the public acceptability of its decision making, and this will be further compounded by the fact that the public will become a consumer upon implementation of a pricing system.

The application of such pricing, and the process through which such a "cost recovery" model will be implemented, is subject to increasing public debate. Ultimately a number of issues will influence the calibration of the future price facing consumers. Key considerations, inter alia, include: achievement of reduced water demand and reduced water wastage (static efficiency); provision of ongoing incentives to encourage investment in water saving technologies (dynamic efficiency); a pricing structure that 
is administratively feasible and easily understandable to consumers; a pricing structure that is seen to be equitable and fair to all consumers; while, at the same time, raising sufficient revenue to sustain and invest in water and wastewater infrastructure, and provide a high-quality service; and also achieve sufficient level of social and political acceptability.

Clearly, the calibration of an appropriate pricing structure is complex, yet it is central to the successful reform of the Irish water sector. Moreover, coordination and prioritization of investment decisions will also be required between local planning authorities and Irish Water. Indeed, local authorities will still raise development contributions for water and wastewater infrastructure benefiting its area (DECLG 2013) and the legislation provides for the funds to be transferred to Irish Water. Therefore, it is important that further research be undertaken to support and study the design of different methodologies for full cost accounting and recovery, a framework for prioritizing investment, and also the new governance approaches that emerge. A meaningful mechanism for the public to engage with the new governance (including regulatory) structures for water resources will be critical to its success for both people and the environment. Ethical considerations, such as fairness in who bears costs and who gains, equity considerations in terms of access to potable water and sanitation, and public and private health and aesthetics will likely be central to present and future evaluations of the emerging governance structures. In light of these points, on the legislative front, additional consideration should be given to a more complete consolidation of legislation to facilitate more efficiency and transparency in delivering, among other things, aquatic ecosystem services, flooding/drought response services, fire response services, etc.

\section{CONCLUSIONS}

There is little doubt that Dublin City and its hinterland are facing pressing water supply challenges. At present it appears that these challenges are still being addressed on a rather ad hoc basic with as yet no clearly apparent integrated management or governance framework, at least not one that encompasses the full suite of water resources management needs beyond potable water supply and sewage treatment. Such a framework would bring together the range of bodies dealing with water supply, flood control, waste assimilative capacity, fisheries, tourism, recreation, etc. At the core of IWRM and explicitly required by the WFD is full cost accounting that recognizes the true economic value of each service. This includes recognition of ecosystem needs and the valuable functions they provide in maintaining the health of Ireland's water supply sources, so called "ecological governance" (Brandes et al. 2005). The advocates for, and managers of, the proposed Shannon water abstraction project need to give due consideration to this in the formal and detailed economic and environmental assessments required to accompany the proposal. In the absence of a published methodology on full cost accounting for the provision of water services in Ireland, the ways in which this will ultimately be achieved in the context of future infrastructure needs and actual charging structures remains somewhat unclear. This being the case, quantitatively analyzing water supply options and associated issues for designing and exploring different approaches for full cost accounting and recovery, and the relationship of these approaches to the Irish Water governance structures would be a useful and logical next step. A role exists for national third-level higher education institutions for the gathering and analysis of these data with a view to researching and supporting the emergence of new and relevant governance approaches and outcomes.

The current spread of responsibilities and competing mandates, if not adequately addressed by the emerging governance structures, will hinder effective urban and indeed national water governance with respect to many of the principles outlined in the introduction. In terms of openness, transparency, participation, and communication, the lingering legacy of past purely top-down, decide-announce-defend approaches remains apparent. Improved citizen participation, e.g., with respect to the emergence of Irish Water, albeit not without its own challenges, is key to increasing openness and transparency. Engaging the public in important technical and scientific issues has always been a challenge, particularly where there are multiple and conflicting objectives.

The extent to which university researchers have become involved in tempering the ensuing debates with independent knowledge has been highly variable from country to country and, in Ireland, has yet to meet its full potential. There is a role for the university academic as the "independent broker" in such debates. The linking of such academics to international networks, such as Universitas 21 , enhances their credibility in such roles. This has not yet been exploited in sustainability debates about Dublin's water supply and opportunities were largely missed in the development of Ireland's river basin management plans (Bruen et al. 2010), although the present authors did contribute to the public consultation phase of the Department of the Environment's consultation on water sector reform water services in Ireland (DECLG 2012). There is evidence that when approached in a sensitive manner, at an early stage and with the right tools, active public consultation can be a success (Stocker et al. 2012).

At present equity is a cornerstone of water availability in Ireland. The challenge is to maintain some degree of this equity while also introducing incentives to use water resources more efficiently and sustainably. This will require among other things policies that further the transition from supply to demand management. Ambiguity about institutional responsibilities in the role of delivering water services is an underlying weakness with respect to accountability. This is likely to get worse in the short term as shares of responsibility change hands from local authorities to Irish Water. In terms of coherency and integration some improvement on this was made by Dublin City in evaluating and proposing the Shannon interbasin transfer. Responsiveness by authorities to short-term, weather-related water shortages and related issues is generally effective (the performance of Irish Water in this regard remains to be seen), but the relevant authorities also need to apply "adaptive management" where institutional arrangements can flex more readily to address long-term issues and unpredictability. It is recognized that these principles can sometimes be in competition with one other, e.g., equity and efficiency, but they nevertheless provide a valuable framework for improving water governance. Overall, there is room for Dublin and Ireland to improve upon efficiency, sustainability, and integrated management of its water resources, and to do so in a transparent manner that reflects the principles of effective governance.

${ }^{[1]}$ Strictly speaking, in terms of geographical extent, the Dublin Region WSA is a subset of the GDA, however the terms Dublin Region WSA and GDA are used slightly interchangeably. 
${ }^{[2]}$ The most recent data $(2007 / 08)$ identifies that $\sim 37 \%$ (national aggregate) of the development contributions collected by local authorities nationwide were expended on water and wastewater infrastructure (DECLG 2013).

Responses to this article can be read online at: http://www.ecologyandsociety.org/issues/responses. $\mathrm{php} / 6921$

\section{Acknowledgments:}

The publication of this paper was supported by a grant from the Seed Funding Scheme, University College Dublin.

\section{LITERATURE CITED}

Asian Development Bank (ADB). 2004. Enhancing the fight against poverty in Asia and the Pacific: the poverty reduction strategy of the Asian Development Bank. ADB, Manila, Philippines.

Aspegren, H., B.-G. Hellström, and G. Olsson. 1997. The urban water system: a future Swedish perspective. Water Science and Technology 35(9):33-43. http://dx.doi.org/10.1016/S0273-1223 (97)00182-0

Bai, X., R. J. McAllister, R. M. Beath, and B. Taylor. 2010. Urban policy and governance in a global environment: complex systems, scale mismatches and public participation. Current Opinion in Environmental Sustainability 2:129-135. http://dx.doi.org/10.1016/ j.cosust.2010.05.008

Bannon, M. J. 1985. The emergence of Irish planning 1880-1920, Turos Press, Dublin, Ireland.

Bel, G., F. González-Gomez, and A. J. Picazo-Tadeo. 2013. The dynamics of privatization and regulation of water services: a comparative study of two Spanish regions. International Journal of Water Resources Development 29:373-384. http://dx.doi. org/10.1080/07900627.2012.721692

Biswas, A. K. 2008. Integrated water resources management: is it working? International Journal of Water Resources Development 24(1):5-22. http://dx.doi.org/10.1080/07900620701871718

Bos, J. J., R. R. Brown, M. A. Farrelly, and F. J. De Haan. 2013. Enabling sustainable urban water management through governance experimentation. Water Science and Technology 67 (8):1708-1717. http://dx.doi.org/10.2166/wst.2013.031

Brandes, O. M., K. Ferguson, M. McGonigle, and C. Sandborn. 2005. At a watershed: ecological governance and sustainable water management in Canada. POLIS Project on Ecological Governance, University of Victoria, Victoria, British Columbia, Canada.

Bruen, M., M. Kelly, W. Magette, E. Gaffey, K. Kochanek, S. Bryan, and R. Hallissey. 2010. WINCOMS: Water Framework Directive - integration, negotiation and communication of optimal measures with stakeholders. STRIVE Report, Environmental Protection Agency, Wexford, Ireland. [online] URL: http://erc. epa.ie/safer/iso19115/displayISO19115.jsp?isoID $=192$
Central Statistics Office. 2012. Census 2011 report: population classified by area. Central Statistics Office, Dublin, Ireland. [online] URL: http://www.cso.ie/en/media/csoie/census/documents/ census 2011vollandprofile1/Census $\% 202011 \% 20-\% 20$ Population $\%$ 20Classified $\% 20$ by $\% 20$ Area.pdf

Clinch, J. P., and E. O'Neill. 2009. Applying spatial economic analysis to national spatial planning. Regional Studies 43 (2):157-178. http://dx.doi.org/10.1080/00343400701808873

Clinch, J. P., and E. O'Neill. 2010. Designing development planning charges: settlement patterns, costs recovery and public facilities. Urban Studies 47(10):2149-2171. http://dx.doi. org/10.1177/0042098009357968

Department of Environment, Community and Local Government (DECLG). 2012. Reform of the water sector in Ireland: position paper. DEHLG, Dublin, Ireland. [online] URL: http://www.environ.ie/en/PublicationsDocuments/FileDownLoad,29192, en.pdf

Department of Environment, Community and Local Government (DECLG). 2013. Development contributions: guidelines for planning authorities. DEHLG, Dublin, Ireland. [online] URL: http://www.environ.ie/en/Publications/

DevelopmentandHousing/Planning/FileDownLoad,32162,en.pdf

Department of the Environment, Heritage and Local Government (DEHLG). 1996. Greater Dublin water supply strategic study meeting Dublin's needs into the 21st Century. DEHLG, Dublin, Ireland.

Dublin City Council. 2010a. Environmental report of the Dublin City development plan 2011-2017: strategic environmental assessment ( $S E A$ ). Dublin City Council, Dublin, Ireland. [online] URL: http://www.dublincity.ie/sites/default/files/content//Planning/ DublinCityDevelopmentPlan/Documents/Dev PlanEnvironmentalReport. pdf

Dublin City Council. 2010b. The plan: water supply project Dublin region. Dublin City Council, Dublin, Ireland. [online] URL: http://dublincity.ie/sites/default/files/content//

WaterWasteEnvironment/WaterSupplyProjectDublinRegion/ WaterSupplyProjectDublinRegion/Documents/The \%20Plan.pdf

Dunne, S., J. Hanafin, P. Lynch, R. McGrath, E. Nishimura, P. Nolan, P. J. Venkata Ratnam, T. Semmler, C. Sweeney, S. Varghese, and S. Wang. 2008. Ireland in a warmer world: scientific predictions of the Irish climate in the twenty first century. Environmental Protection Agency, Wexford, Ireland.

European Commission (EC). 2000. Water Framework Directive 2000/60/EC establishing a framework for community action in the field of water policy. Official Journal of the European Communities L327:173.

European Commission (EC). 2012. Environment: Commission refers Germany to court over incomplete cost recovery for water services. European Commission, Brussels, Belgium. [online] URL: http://europa.eu/rapid/press-release IP-12-536 en.htm? locale $=$ en 
European Environment Agency (EEA). 2012. Territorial cohesion and water management: the spatial perspective. European Environment Agency Technical Report No. 4/2012. Publications Office of the European Union, Luxembourg.

Fischhendler, I., and T. Heikkila. 2010. Does integrated water resources management support institutional change? The case of water policy reform in Israel. Ecology and Society 15(1): 4. [online] URL: http://www.ecologyandsociety.org/vol15/iss1/art4/

Forfás. 2008. Assessment of water and wastewater services for enterprise. The National Policy and Advisory Board for Enterprise, Trade, Science, Technology and Innovation, Dublin, Ireland.

Franks, T. 2004. Water governance: What is the consensus? Paper prepared for the ESRC-funded seminar on The water consensus: identifying the gaps. Bradford Centre for International Development, Bradford University, Bradford, UK.

Gkartzios, M., and M. Scott. 2009. Planning for rural housing in the Republic of Ireland: from national spatial strategies to development plans. European Planning Studies 17(12):1751-1780. http://dx.doi.org/10.1080/09654310903322298

Global Water Partnership (GWP). 2000 Integrated water resources management. Technical Advisory Committee (TEC) Background paper no. 4. GWP, Stockholm, Sweden.

Helmer, R., and I. Hespanhol, editors. 1997. Water pollution control: a guide to the use of water quality management principles. E \& FN Spon, London, UK.

Irish Academy of Engineering. 2007. Ireland at Risk, No. 1: the impact of climate change on the water environment. Irish Academy of Engineering, Dublin, Ireland. ISBN: 1898012 938. [online] URL: http://www.iae.ie/publications/publication/part-1-irelandat-risk-water/

Irish Government. 2013. Water Services Act. Government Publications, Dublin, Ireland.

Kallis, G., M. Kiparsky, and R. Norgaard. 2009. Collaborative governance and adaptive management: lessons from California's CALFED Water Program. Environmental Science and Policy 12 (6):631-643. http://dx.doi.org/10.1016/j.envsci.2009.07.002

Kildare County Council. 1999. Kildare water strategy. Kildare County Council, Kildare, Ireland. [online] URL: http://kildare. ie/countycouncil/publications/WaterStrategy/

Lankford, B., B. van Koppen, T. Franks, and H. Mahoo. 2004. Entrenched views or insufficient science? Contested causes and solutions of water allocation: insights from the Great Ruaha River Basin, Tanzania. Agricultural Water Management 69(2):135-153. http://dx.doi.org/10.1016/j.agwat.2004.04.005

Lautze, J., S. de Silva, M. Giordano, and L. Sanford. 2011. Putting the cart before the horse: water governance and IWRM. Natural Resources Forum 35:1-8. http://dx.doi.org/10.1111/j.1477-8947.2010.01339. $\underline{x}$

Leahy, P. G., and G. Kiely. 2011. Short duration rainfall extremes in Ireland: influence of climatic variability. Water Resources Management 25:987-1003. http://dx.doi.org/10.1007/s11269-010-9737-2
Lubell, M. N., and L. Lippert. 2010. Integrated regional water management: collaboration or water politics as usual? Technical Completion Reports, University of California Water Resources Centre, Riverside, California, USA.

Manzungu, E., and C. Mabiza. 2004. Status of water governance in urban areas in Zimbabwe: some preliminary observations from the city of Harare. Physics and Chemistry of the Earth 29:1167-1172. http://dx.doi.org/10.1016/j.pce.2004.09.003

Met Éireann. 2014. Mean annual rainfalls from 1981 to 2010. Met Éireann, Dublin, Ireland. [online] URL: http://www.met.ie/ climate-ireland/rainfall.asp

Misstear, B. D. R., L. Brown, and P. M. Johnston. 2008. Estimation of groundwater recharge in a major sand and gravel aquifer in Ireland using multiple approaches. Hydrogeology Journal 17(3):693-706. http://dx.doi.org/10.1007/s10040-008-0376-0

McElwain, L., and J. Sweeney. 2003. Climate change in Ireland recent trends in temperature and precipitation. Irish Geography 36:97-111. http://dx.doi.org/10.1080/00750770309555815

Organisation for Economic Co-operation and Development (OECD). 2011. Water governance in OECD countries: a multilevel approach. Studies on Water. OECD, Paris, France. [online] URL: $\underline{\text { http://dx.doi.org/10.1787/9789264119284-en }}$

Organisation for Economic Co-operation and Development (OECD). 2013a. Making water reform happen in Mexico. OECD Studies on water. OECD, Paris, France. http://dx.doi. org/10.1787/9789264187894-en

Organisation for Economic Co-operation and Development (OECD). 2013b. OECD water governance initiative. [online] URL: http://www.oecd.org/gov/regional-policy/Terms-of-Reference $\% 20$ OECD-WGI.pdf

Rahaman, M. M., O. Varis, and T. Kajander. 2004. EU water framework directive vs integrated water resources management: the seven mismatches. International Journal of Water Resources Development 20(4):565-575. http://dx.doi.org/10.1080/07900620$\underline{412331319199}$

Redmond, D., B. Williams, B. Hughes, and J. Cudden. 2012. Demographic trends for Dublin. Think Dublin! Research Series. Dublin City Council, Dublin, Ireland.

Rijke, J., M. Farrelly, R. Brown, and C. Zevenbergen. 2013. Configuring transformative governance to enhance resilient urban water systems. Environmental Science and Policy 25:62-72. http://dx.doi.org/10.1016/j.envsci.2012.09.012

Rogers, P., and A. Hall. 2003. Effective water governance. Global Water Partnership, Stockholm, Sweden.

Schreiner, B., and B. van Koppen. 2003. Policy and law for addressing poverty, race and gender in the water sector: the case of South Africa. Water Policy 5(5-6):489-501.

Stocker, L., G. Burke, D. Kennedy, and D. Wood. 2012. Sustainability and climate adaptation: using Google Earth to engage stakeholders. Ecological Economics 80:15-24. http://dx. doi.org/10.1016/j.ecolecon.2012.04.024 
Trow, S., and M. Farley. 2006. Developing a strategy for managing losses in water distribution networks. Pages 141-179 in D. Butler and F. A. Meon, editors. Water demand management. First edition. ISBN: 1843390787. IWA Publishing, London, UK.

UNESCO. 2009. Water in a changing world. United Nations World Water Assessment Programme. UNESCO, Paris, France.

Water Governance Centre. 2013. Water governance capacity Awash Basin, Central Ethiopia. Issues paper, Water Governance Centre, The Hague, Netherlands. 